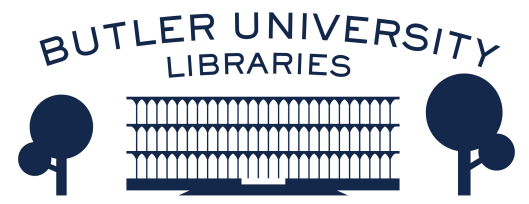

Journal of Hindu-Christian Studies

Volume 26

Article 3

November 2013

\title{
The Traditional Roots of Difference
}

Anantanand Rambachan

St. Olaf College

Follow this and additional works at: https://digitalcommons.butler.edu/jhcs

Part of the Religion Commons

\section{Recommended Citation}

Rambachan, Anantanand (2013) "The Traditional Roots of Difference," Journal of Hindu-Christian Studies: Vol. 26, Article 3.

Available at: https://doi.org/10.7825/2164-6279.1542

The Journal of Hindu-Christian Studies is a publication of the Society for Hindu-Christian Studies. The digital version is made available by Digital Commons @ Butler University. For questions about the Journal or the Society, please contact cbauman@butler.edu. For more information about Digital Commons @ Butler University, please contact digitalscholarship@butler.edu. 


\title{
The Traditional Roots of Difference
}

\author{
Anantanand Rambachan \\ St. Olaf College
}

IN Being Different: An Indian Challenge to Western Univeralism, Rajiv Malhotra, drawing from and building on earlier lines of argument offered by, among others, Sri Aurobindo and Richard Lannoy, attempts to identify crucial differences in the worldviews of what he refers to as the Judeo-Christian religions and Indian thought. These contrasts are presented with the aim of contesting the so-called universalism of the Judeo-Christian world-view and highlighting the value and even superiority of the Indian perspective. He identifies his method with the ancient practice of pūrvapakșa that involves grasping the opponent's view, refuting it and demonstrating the truth of one's position.

I welcome this effort by Malhotra, continuing the work of thinkers on the Indian side like Aurobindo and Gandhi, and engaging the significance of these issues in our contemporary world context. Western colonialism, with its assumptions about universality and superiority, had deep and lasting impacts on both colonizer and colonized. The latter became the object of inquiry, with methodologies that adopted uncritically the colonizer's assumptions. The work of uncovering and interrogating these assumptions is ongoing and necessary and Malhotra's work is a contribution in this effort. The colonizer's reading of the meaning of the colonized religious and cultural heritage is pervasive and has become, in many respects, normative. Peeling away the layers of interpretation is arduous and painstaking. Malhotra has certainly chipped away at some of these layers and even peeled back a few, drawing attention, for example, to differences in the significance of history, time, and in responses to diversity. He rightly cautions us that the globalized world is not a "flat world" but one in which "the deeper structures that support the power and privilege of certain groups are stronger than ever" (p.14). Malhotra must be commended for pursuing these issues in Being Different and for affirming the importance of religious differences.

Any grand work, like that of Malhotra, aiming to undertake a comparison of the history and culture of two or more civilizations risks generalizations. Malhotra is not unaware of this problem and confesses a wish to avoid sweeping and misleading generalizations

Dr. Anantanand Rambachan is Professor of Religion at Saint Olaf College, Minnesota, USA, where he has been teaching since 1985. His major books include Accomplishing the Accomplished (University of Hawaii Press, 1991), Gitamrtam: The Essential Teachings of the Bhagavadgita (Motilal Banarsidass 1993), The Limits of Scripture (University of Hawaii Press 1994), The Hindu Vision (Motilal Banarsidass 1999), The Advaita Worldview: God, World and Humanity (SUNY 2006), and A Hindu Theology of Liberation ( SUNY: forthcoming 2014). 
(p.105). This laudable intention, however, does not exonerate the writer from problematic generalizations, especially when the central concern of the discussion is the affirmation and celebration of difference and uniqueness. There are many, especially from the Jewish tradition, who would question the construction of the category of "Judeo-Christian," and Christians who would dispute his representation of Christian doctrine and theology. My focus in this review is on Malhotra's discussion of Hindu traditions.

Although the concern in Being Different is to speak for the so-called dharma traditions, that is those originating in the Indian sub-continent, his focus is significantly on the Sanskrit texts and heritage. ${ }^{1}$ Within this focus, the voices of the Hindu traditions are heard most often, and, among these voices, the drumbeat (dindima) of Advaita Vedānta prevails. Malhotra speaks of all dharma traditions as affirming a belief in the "innate oneness" of reality (p.102), but this generalization overlooks the dualism of classical Yoga, the pluralism of Jainism, and the philosophical complexities of the Buddhist tradition. Malhotra's clarification of consequential differences between the traditions of India and Judaism and Christianity can be pursued without the homogenization into which his discussion too often slips, but this will require a greater readiness to engage the rich theological diversity of the traditions of India and to identify the specific roots of his arguments.

My concern with Malhotra's treatment of the Hindu traditions goes deeper and, since his arguments, as I read these, are derived principally from the Advaita tradition, I will confine my major comments to his representation of this sampradaya. In a work that devotes itself so appropriately and extensively to the nature and sources of knowledge, as well as to the grounds for comparing truth claims, I found it surprising that there was no discussion of the centrality and significance of pramāna to the Vedānta traditions or any effort to situate his discussion in relation to classical epistemologies. This subject is important if Malhotra is seeking to locate his work centrally in Indian classical traditions. If, on the other hand, he wishes the reader to see his work as a novel and fresh interpretation of the tradition, it is necessary to clarify his differences with earlier formulations and to make the case for the advantages of his construction. As noted earlier, the specific sources, traditional and otherwise, that inform his position deserve better identification in the main body of this work.

Those who are familiar with my work know of my efforts to counter interpretations of Advaita that, for various reasons, overlook the centrality of the Veda as a pramanna in the methodology of classical Advaita and instead propose experience (anubhava) as the conclusive source of our liberating knowledge of brahman. ${ }^{2}$ Valid knowledge (pramā) according to the Advaita Vedānta tradition is knowledge that conforms to the nature of the object which one seeks to know (vastutantram). Valid knowledge can be generated only by the application of a valid and appropriate means of knowledge, referred to as a pramāna. For Śankara, the Veda and more specifically the Upanisad, is the single and unique source of liberating knowledge about the nature of brahman. It satisfies the criteria of being a source of valid knowledge (pramāna) by the fact of its unique subject matter (anadhigata), its non-opposition to other valid sources of 
knowledge (abhädita) and the usefulness of its revelations (phalavath artha bodhaka). It is also clear that Śankara and his disciples regard the Veda as a revelation from brahman, conveyed to the $r$ șis as word-constituted mantras. ${ }^{3}$ This wisdom, in the Advaita understanding, is then conveyed from teacher to qualified student in a sampradāya or line of transmission.

Overlooking the methodology and significance of the Veda as a pramāna, Malhotra adopts a science model to characterize the process and gain of wisdom in the dharma traditions. "The dharma family (Hinduism, Buddhism, Sikhism and Jainism)," writes Malhotra, "have developed an extensive range of inner sciences and experimental technologies called 'adhyātmavidya' to access divinity and higher states of consciousness. Adhyātmavidya is a body of wisdom and techniques culled from centuries of firstperson empirical inquiry into the nature of consciousness undertaken by advanced practitioners (p.6)." Disregarding the classical arguments for the Veda pramāna, Malhotra speaks of the autonomous discovery of this teaching by anyone (p.56) and of the aspirant's freedom to start afresh (p.56). He writes of the acquisition of knowledge through direct experience and empirical testing (p.61). Without engaging or responding to the Upanișad teaching that the atmā, as nonobjectifiable, ultimate subject, cannot be known through sense perception (indriya pratyakșa) or through any process of internal cognition (sākși pratyakșa), Malhotra speaks of the inner sciences developed through observation and experimentation. Any methodology of knowing proposed, however, must be related logically to the nature of the object that one seeks to know (pramāna prameya sambandha). The unavailability of the $\bar{a} t m \bar{a}$ for any kind of objectification is particularly important in this context. To observe the $\bar{a} t m \bar{a}$ as an object would require another illumining awareness and awareness cannot be bifurcated into subject and object. As Yājñavalkya puts it in Bṛhadāranyaka Upaniṣad (3.4.1), "You cannot see that which is the witness of vision; you cannot hear that which is the hearer of hearing; you cannot think that which is thinker of thought; you cannot know that which is the knower of knowledge."4 The scientific analogy is deepened with Malhotra's claim that the Indian traditions make no claims of finality of knowledge (p.42). The Advaita tradition is certainly cognizant of the limits of language and all symbol systems in conveying knowledge of brahman, but it claims also to offer a liberating teaching that is not tentative or uncertain. It will be helpful to have further clarification from Malhotra on this issue. The epistemological model that one advocates must be appropriately related to the subject of one's inquiry.

From the perspective of the classical Advaita tradition, as systematized and expounded by Śankara, the employment of a science analogy to describe the method of acquiring knowledge of the $\bar{a} t m \bar{a}$ is problematic. It implies that the revelations of the Vedas are available through methods similar to those employed in the empirical sciences. This would undermine the claim of the Veda to be a pramanna with a unique subject matter. It would mean that brahman is no longer outside the scope of perception and inference (external and internal) and the Veda pramāna becomes redundant. This comment is not meant to suggest that the effort by Malhotra, or any other contemporary interpreter, to offer 
alternative epistemology on the model of scientific inquiry, is illegitimate. My concern is that such a model must not be presented or assumed as the traditional one, and that the case for it in relation to the classical Vedapramāna model needs to be explicitly argued and critically defended. The employment of the terminology of science to describe a mode of religious knowing does not immediately confer upon it uncritical legitimacy, and the limits of scientific models deserve critical scrutiny.

What is interesting about the use of the scientific metaphor to speak of the process of gaining knowledge in the Indian traditions is that it developed under a specific constellation of historical factors and in response largely to the western impact on India. Malhotra's discussion, whether he recognizes it or not, has continuities with this historical process. In the Limits of Scripture, I trace the circumstances in the Brahmo Samaj, in the late nineteenth century, when there was discomfort and embarrassment over the traditional authority of the Veda in debates with Christian missionaries. This led to its formal rejection and replacement with intuition. ${ }^{5}$ The idea of personal experience as an immediate source of religious knowledge rose to prominence and became a leading idea of the period and a dominant motif of contemporary Hinduism. Personal experience was championed as sacrosanct and unquestionable. Unitarian Christian thinkers like William Channing and Theodore Parker influenced also its formulation. Swami Vivekananda inherited the skepticism and mistrust of scriptural authority championed by Brahmo Samaj leaders and contributed to re-casting Hindu epistemology on the model of his understanding of scientific inquiry. In doing so, Vivekananda himself offers an alternative to the more traditional understanding of Vedānta epistemology based on the centrality of the Upanișad pramāna. He doe not offer, therefore, any detailed treatment of the Veda as a pramāna in his writings. The term is never employed directly by him, except on the one occasion of his commentary on the Yoga-sūtras of Patañjali. Aurobindo, the Indian thinker most profusely quoted by Malhotra, was deeply influenced by Vivekananda. He read Vivekananda extensively and reflects also the centrality of personal experience in his epistemology.

Science as a method of attaining knowledge and as the key to human progress was enjoying considerable prestige among the Bengali intelligentsia in the nineteenth century. ${ }^{6}$ Vivekananda spoke of the scriptures as a collection of truths discovered through the experimentation of the various rșis at different times. Each one of us, according to Vivekananda, must validate these teachings in our own experiences, by following the methods prescribed. Malhotra phrases this argument in similar terms, claiming that, "direct experience and empirical testing are important for the acquisition of knowledge. Truth is to be discovered and rediscovered for oneself, an endeavor that requires active inner and outer engagement (p.61)."

Malhotra's attempt to re-cast the Hindu tradition on the model of science, indebted as it is to earlier historical efforts, presents us with many similar problems. It does not engage sufficiently the radical differences between the objects of scientific inquiry and the $\bar{a} t m \bar{a}$ that, as the ground of all cognitive processes and the ultimate subject, is not available for knowledge though any process of objectification, internal or external. While championing the supremacy 
of personal experience, it overlooks the complexity of experience in religion and science. It assumes a self-validity and selfinterpretativeness that does not grapple with the complexity of the relationship between experience and interpretation. It assumes also a singular experience of samādhi across the Indian traditions, that requires ignoring the doctrinal diversity of the dharma traditions and, in particular, the dualism of Yoga where the nature of samādhi is best expounded. In reality, there is no single defining experience championed uniformly by all Indian traditions. It is problematic, to say the least, for any interpreter to bypass the different worddescriptions of culminating experiences and to claim that these are alternative ways of speaking about the same experience. If Malhotra's epistemological arguments are different and if these questions are inapplicable, then a substantial clarification from him will be helpful to this conversation. I offer this perspective, not to superimpose simplisltically an earlier critique on Malhotra, but because of the historical continuities and overlapping arguments that I discern in Being Different. A critique is not discredited because it was advanced earlier. If the arguments made are essentially the same, then questions remain valid.

One of the consequences of Malhotra's disregarding the classical understanding of the Veda as śabda pramāna, and his use of a science model centering on the validity of personal experience, is an underplaying of the cognitive significance of the mantras of the Vedas and a clear emphasis on what he presents as their vibratory power. "Their deepest truth," writes Malhotra, " is vibratory in nature, and these vibrations can take us to levels of consciousness that transcend language (p.227)." Certainly, the Hindu traditions have emphasized the significance of right sound in the articulation and power of mantras. To overlook this is to miss something vital in the nature of a mantra. At the same time, Hindu theological traditions emphasize that the mantras fulfill their purpose also in communicating a teaching about the nature of reality. This follows from the right comprehension of the meaning of the mantras. To ignore this is also to miss something central to the nature of mantras, especially those that constitute the Upanișads. The significance of meaning explains the development of sophisticated norms and tools of exegesis referred to as șadlinga that were developed by Pūrva Mīmāmsa exegetes and adopted by later Vedānta commentators. A sampradāya is a lineage of transmission, but also one of exegesis and pedagogy. Comprehension was important because the attainment of liberation itself was at stake. It is unfortunate that this dimension of the significance of Veda mantras, that explains so much of the intellectual vitality and energy of the classical tradition, receives minimal treatment in Malhotra's discussion. My point, to make it absolutely clear, is not that sounds and vibrations are not unimportant. I contend, however, that these cannot be emphasized to the exclusion of meaning. The significance of the mantras is multi-dimensional and one hoped for some recognition of this fact in Malhotra's work.

I believe also that Malhotra's one-sided emphasis on the vibrational character of Sanskrit leads to his argument for the fundamental non-translatability of the language. I share his concern about the dangers of forcing the artifacts of one culture into the 
mould of another (p. 221), and his caution about the challenges, and even impossibility, in some cases, of easy translation. The issue of translation, however, though always challenging, presents different possibilities when the concern is with the communication of meaning. Meticulous care and linguistic competence are necessary if unique categories are not to be lost, but this is different from the radical claim of non-translatability advanced by Malhotra in Being Different. An alternative position is advanced by Swami Dayananda Saraswati, a distinguished contemporary teacher of Advaita, who argues that the Veda pramanna, and especially the teaching of the Upanișads, cannot be linked inseparably to a specific language and has no inextricable link with Sanskrit. It can be available and transmitted in other languages. ${ }^{7}$ This requires a skillful teacher, schooled deeply in the methodology of the tradition and rooted in its vision of reality, but liberating wisdom is not language-specific. ${ }^{8}$ To make an argument for the absolute non-translatability of Sanskrit is to imply also that the wisdom of the Hindu tradition is not accessible to someone without knowledge of the language.

My final specific comment concerns Malhotra's critique of "tolerance" as a mode of relationship between religions. In his problematizing of tolerance, Malhotra stands with earlier commentators like Elizabeth Spelman and Diana Eck who made similar observations. ${ }^{9}$ There is much to concur with in this critique, especially the assumptions of power and privilege inherent in the idea of tolerating another. Malhotra proposes replacing tolerance with "mutual respect." I found it difficult, however, to determine whether "mutual respect," as described by
Malhotra, referred to an ethics of interreligious relationships, or a theology of religious diversity. What does it mean, for example, in the words of Malhotra, "that we consider the other to be equally legitimate (p.16)?" Do we mean legitimate for him or her or are we speaking of legitimacy in a more universal sense? Does legitimacy imply that all religious claims have equal validity? Perhaps "mutual respect" is both ethical and theological, but the theology underlying "mutual respect" needs more critical unpacking. In describing an encounter (p. 21-22) in New Delhi with a delegation from Emory University, Malhotra clarified that respect means acknowledging other religions "to be legitimate and equally valid paths to God." If we have in this statement the gist of Malhotra's theology of religious diversity, is there not something amiss with his labors in this work to establish religious difference and to argue for the rational superiority of the traditions of India? Or am I missing something? The theology of religious diversity implicit in Being Different certainly needs more clarification and its similarities and differences from earlier models highlighted and argued.

My reflection on Malhotra's representation of the Hindu traditions is not meant to delegitimize the lens through which he reads. I do want, however, to particularize and contextualize historically this reading as one that developed substantially in response to Christian missionary criticism in the nineteenth century and in response to the encounter with western science. Earlier Hindu interpreters were concerned, like Malhotra today, to show that the tradition had a methodology distinct from Christianity that was Bible-centered, authoritarian and closed to 
the findings of empirical inquiry. They wanted to demonstrate that Hindu traditions employed scientific-like methodologies and that their findings were consistent with the claims of science. This led to a decisive rejection and reinterpretation of the traditional authority of the Veda and its nature as a revealed teaching. The pramanna method of approach that I discuss here is also a specific lens, but it is an indigenous one with deep roots in the history of the tradition. We cannot rush to characterize it as "scientific" without careful clarification of the methodology and field of inquiry for science. It is a rational approach, deeply concerned not to contradict or be contradicted by the findings of other valid sources and is willing to open itself to the interrogation of these sources. It is very important that in any effort to distinguish ourselves from the other and to affirm our difference, we do not negate our identity.

I applaud Malhotra's passion to resist homogenization of the Hindu tradition and to affirm difference from other traditions. How and where we identify and describe these differences must be the focus of fruitful and respectful intra-Hindu and interreligious conversation. Intellectually honest and vigorous intra-religious conversation is as important as interreligious ones and, in many cases, even more challenging. There is a long history of vigorous theological debate among the traditions of India exemplifying care in the public articulation of the opponent's viewpoint and without the distraction of treating dissent as disloyalty to a community, nation-state or tradition. May this heritage inspire our own dialogical engagement.

\section{Notes}

${ }^{1}$ Although the expression "dharma-traditions" is used in circles of discussion, the meaning and value of the formulation deserves critical discussion. It is not clear what is meant beyond identifying a tradition originating from the Indian sub-continent. There may be value in its use, but this is yet to be clarified.

${ }^{2}$ See Anantanand Rambachan, Accomplishing the Accomplished: The Vedas as a Source of Valid Knowledge in Śankara (Honolulu: University of Hawaii Press, 1991). Also, Anantanand Rambachan, The Limits of Scripture: Vivekananda's Reinterpretation of the Vedas (Honolulu: University of Hawaii Press, 1994).

${ }^{3}$ Śankara's understanding of the origin of the Veda is discussed in his commentary on the second sūtra of the Brahmasūtra.

${ }^{4}$ The issue of how knowledge of the knower is gained is a vital one for the Vedānta tradition. For my discussion of this dilemma and resolution see, Anantanand Rambachan, The Advaita Worldview: God, World and Humanity (Albany: State University of New York Press, 2006). See Chapter 4.

${ }^{5}$ See Anantanand Rambachan, The Limits of Scripture, Chapter 1.

${ }^{6}$ See David Kopf, The Brahmo Samaj and the Shaping of the Modern Indian Mind (Princeton: Princeton University Press, 1979), Chapter 2.

${ }^{7}$ Swami Dayananda Saraswati, Dialogues with Swami Dayananda, (Rishikesh: Sri Gangadhareswar Trust, 1988).

${ }^{8}$ For the purpose of disclosure, let me state that I regard myself as a disciple of Swami Dayananda Saraswati. I studied Advaita Vedānta intensively with him for three years in India and my understanding and discussion of 
the tradition is deeply informed by his pramāna-based approach to teaching.

${ }^{9}$ See Elizabeth Spelman, Inessential Woman: Problems of Exclusion in Feminist Thought (Boston: Beacon Press, 1988), 182. Also Diana Eck, Encountering God (Boston: Beacon Press, 1993), 192-193.

http://dx.doi.org/2027/mdp.39076002049885 